\title{
熟練・準熟練剣道選手における反応選択の処理効率差 \\ 奥村 基生 吉田 茂 \\ Differences in processing efficiency of response selection between skilled and sub-skilled kendo players
}

\author{
Motoki Okumura and Shigeru Yoshida
}

\begin{abstract}
A study was conducted to examine the processing efficiency of response selection in collegiate kendo players. Skilled and sub-skilled groups (each $n=8$ ) reported their skill knowledge utilized in practices and matches. Experimental tasks in which subjects found and attacked the vulnerable points of an opponent were solvable with skill knowledge, and had three levels of difficulty. For the tasks, the two groups participated in a motor skill confirmation experiment, and a response selection experiment with environmental interference (with and without attacks by an opponent). Five attacking trials were allowed for one subject in each task. It was verified that both groups had acquired skill knowledge and motor skills of the same grade. Although the thinking processes in response selection were almost the same in both groups, the skilled group used their skill knowledge more frequently and had higher scores in terms of time efficiency and skill exertion. The results showed that the skilled group selected responses actively and frequently by anticipating with their skill knowledge, and this processing function was robust against environmental interference. Such active response selection, which differs from the passive processing of environmental information by skilled players in other studies, indicates that the processing mode in response selection changes according to the characteristics of a sport. Kendo players should acquire effective skill knowledge, then utilize it actively and frequently in response selection in order to refine that knowledge and reinforce the processing function.
\end{abstract}

Key words : expertise, skill knowledge, processing function, processing mode, sports characteristics

(Japan J. Phys. Educ. Hlth. Sport Sci. 51: 459-470, July, 2006)

筑波大学人間総合科学研究科（体育科学）

干 305-8574 茨城県つくば市天王台 1-1-1

連絡先 奥村基生
Graduate School of Comprehensive Human Sciences (Physical Education, Health and Sport Sciences), University of Tsukuba 1-1-1 Tennodai, Tsukuba, Ibaraki 305-8574

Correspondingauthor okumura@taiiku.tsukuba.ac.jp 
キーワード：熟練, 技知識, 処理機能, 処理様相, 競技特性

\section{Iはじめに}

剣道競技（以下，「剣道」と略す）は，直接の 対戦と身体の接触がある 1 対 1 の攻防一体型の競 技である.その攻防は, 約 $2 \mathrm{~m}$ 内の距離において 身体と竹刀の不確定な動作を介して, 連続かつ高 速で展開される。剣道のような開放技能において は, 高次戦術の獲得や発揮が重要となるため, 動 作を決定する反応選択の優劣が競技結果の成否に 大きな影響を及ぼす。

反応選択の熟練過程を検討する研究では, 実験 課題や試合における動作を戦術的観点から分類す ると同時に，処理した情報を言語報告によって抽 出して分析することが多い。これまで, ベースボ ール (French et al., 1996 ; Nevett and French, 1997), 卓球 (Sève et al., 2002 ; Sève et al., 2003）などのボールゲームにおいて熟練差が検討 されている，たとえば，テニスにおける成人の熟 練選手は初心者と比べて, 実戦環境に対応して適 切な反応選択をすることが示されている (McPherson, 1999, 2000).

ここで，反応選択の熟練に関わる要因として処 理機能と処理効率を取り上げて説明を加える. 処 理機能は, 環境や知識などの様々な情報を活用す るための処理システムの機能とする.処理効率は, 結果として動作にも反映する反応選択の正確性や 速度とする，この定義に沿うと, 熟練選手は豊富 な知識を獲得して恒常的に活用することによっ て, 適切な情報の符号化と知識を検索するための 処理機能を効率化して, 最終的に処理効率を向上 させる，一方，初心者は符号化不全や知識不足の ために処理効率が低下する（Ericsson and Kintsch, 1995 ; McPherson and Kernodle, 2003 ; Tenenbaum, 2003).

これらの熟練選手の卓越した反応選択の説明で は，環境や動作そして戦術などの競技に関連した 情報を結合した知識の獲得を想定している。なぜ なら, 作動記憶の処理許容量や競技の時間制約が,
種々の情報を必要に応じて再構築することを許さ ないためである。つまり, 熟練選手は, 複合情報 が含まれる知識を高次の情報資源として獲得し て, 反応選択において活用することで高い処理効 率をもたらしている。この効率的かつ機能的な知 識活用は, ACT * (adaptive control of thought star：Anderson, 1987）などの認知領域の理論 を引用して説明される（Masson，1990； Williams et al., 1999).

このような理論的説明は，環境情報の符号化と 活用を前提としている。 その前提は，競技におけ る認知的熟練を取り上げた近年の著書にも強く反 映されている（Starkes and Ericsson, 2003 ; Williams et al., 1999). 確かに, 競技に関連した 情報を結合した知識の獲得と活用は, 環境情報に 対応して正確で迅速な反応をもたらす知覚的熟練 (Mori et al., 2002 ; Williams and Elliott, 1999) や，先述のボールゲームでの文脈や環境情報に基 づく反応選択の熟練についての理解を促す.

しかし，多くの競技では，一般の認知課題とは 異なり，環境情報に対応して受動的に反応選択を するだけではない. 特に, 剣道のような個人競技 や集団競技の 1 対 1 場面では, 環境情報への依存 性が低くとも, 能動的な動作によって環境変化を 誘発することができる.すなわち, 獲得された知 識は, 環境変化を予測する能動的な反応選択にお いても有効に活用されるはずである。これは，反 応選択のための思考方法には, 環境情報に対して 受動的あるいは能動的な処理様相の両方が存在す ることを意味する.だが, 先行研究では, この点 を考慮せず，一貫して受動的な反応選択の熟練差 が強調されてきた。つまり, 反応選択の処理様相 の受動性・能動性については, その熟練差や競技 特性による変動の観点から具体的に検討がなされ ていない。これを検討することは，予測をもたら す意図的・能動的な知識活用のための処理機能に ついても議論することになる。

また, 先行研究では, 反応選択のための情報資 源として運動技能の獲得も必要であるという (French et al., 1996). しかし, 被験者の基礎的 な競技規則の知識や運動技能（たとえば，テニス 
のグラウンドストローク）の獲得度合などは測定 しているが (French and Thomas, 1987 ; McPherson and Thomas, 1989), 実験課題や試 合で活用した知識や運動技能の獲得度合の差異を 確認していない. そのため, 反応選択の処理効率 の熟練差が, 獲得した知識や運動技能のような情 報資源の差異であるのか, 思考方法や知識検索の ような処理様相や処理機能の相違であるのかが曖 昧である。

本研究では，3つの実験課題を実施する．まず， 熟練水準が異なる 2 群の大学生の剣道選手が練習 や試合の攻撃において意図的に活用する技の知識 （以下，「技知識」と略す）を確認する。これは, 動作や戦術の情報などを結合した知識であり，反 応選択において活用される主要な情報資源になる と考えられる (奥村・吉田, 2002). そして, こ の技知識によって攻撃の成功が可能な実験条件を

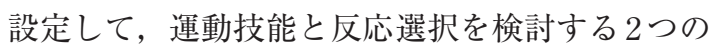
実験課題を実施する。つまり，最初に実験条件に 対する技知識を統制し，運動技能の獲得度合を検 討することによって, 情報資源に相違があるかど うかを確認する。そして，実戦環境に類似するよ うに環境干渉（対戦相手による攻撃可能性）が存 在する課題を設定して, 反応選択の処理効率の熟 練差を検証する。このようにして獲得した情報資 源の差異と, それを実戦環境において発揮する能 力の関係を検証する. 加えて, 熟練水準間に存在 する処理様相や処理機能の相違を観察して, 反応 選択の処理効率に及ぼす影響を考察する.同様に， 競技特性から生じる反応選択の処理様相の特徴を 論じる。

\section{II 方法}

\section{1. 被験者}

筑波大学体育会剣道部員の男性 16 名に実験内 容を説明して参加承諾を得た. 被験者を大学公式 戦のレギュラー選手であり全国大会の優勝経験が ある選手で構成した熟練群（特徵の平均（標準偏 差）は, 年齢：20.3（1.6）歳, 経験年数： 13.6 （2.4）年，段位：3.1（0.4）段）と，それ以外の
選手で構成した準熟練群（年齢：20.7（1.3）歳, 経験年数：12.8（1.6）年，段位：2.9（0.4）段） の 2 群に 8 名ずつ配置した。

\section{2. 実験課題}

1）知識確認実験

被験者が練習や試合で意図的に活用する技知識 を確認した. 方法は, 先行研究 (奥村 - 吉田, 2002）に準拠したが，技の種類（たとえば，しか け技や応じ技）を限定せずに全ての技を報告する ように要請した。実験期間は被験者の技知識の獲 得数に依存して 1 - 2 ヶ月に渡った。 なお, 本研 究では後述の 2 実験課題の条件を設定するため に，しかけ技をしかけ技・出ばな技・引き技の 3 つに細分類し, さらに応じ技と合わせて 4 分類と した。

2）技能確認実験

知識確認実験の結果から実験条件を設定して, その条件に対する運動技能の獲得度合を確認し た。

\section{(1) 実験条件}

まず，被験者 16 名の中で 15 名が参加した試合 の実験において, 攻撃の成功が多かった 2 種類の 技（計 560 本中にしかけ技 210 本，引き技 155 本） によって攻撃の成功が可能な条件を設定すること にした。この 2 種類の技は, 主に攻撃者が単独で 攻撃する特徵がある。なお，知識確認実験におけ るしかけ技と引き技の知識数の平均（標準偏差） は, 熟練群が62.8（12.6）件，準熟練群が 40.1 （15.1）件であった. 次に, 評価者 2 名（経験年数 それぞれ 22 年, 16 年) が知識確認実験の結果を 参照して条件を設定した (図 1 )。ここでは，3 難 度の条件を設定し, 低難度では 3 部位（面, 小手, 胴）で 2 部位, 中難度で 1 部位の攻撃の成功が可 能であった。高難度は全ての部位に対して攻撃の 成功が困難であった。なお，部位が小さく攻撃の 成功が難しい突きは除外した。各難度で 3 条件, 全 18 条件を設定した（2種類の技 $\times 3$ 難度 $\times 3$ 条 件).この低・中難度の条件が既知であれば攻撃 の成功は容易である。最後に, 評価者 2 名は, 全 ての被験者が低・ 中難度に対応する技知識を獲得 


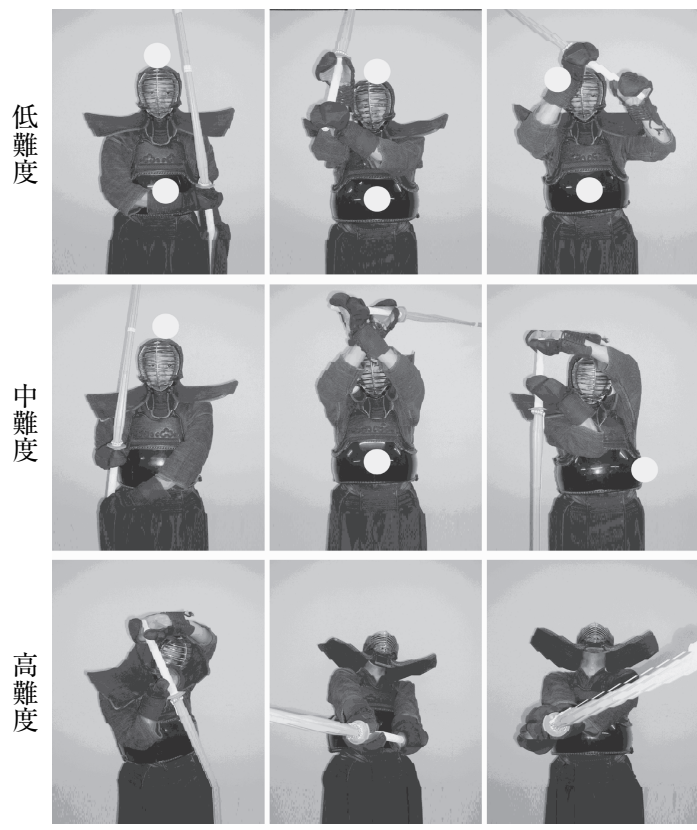

白丸は攻撃成功が可能な部位

図1引き技の実験条件の例

していることを再確認した。

（2）実験手順

被験者が常用する練習施設において, 実験者, 防御者，被験者の 3 名の実験環境を設けた。実験 者は, 適合する戦術を用いて迅速かつ正確に攻撃 するように被験者に教示した。

試行の開始は，しかけ技の実験条件では両者が 開始線（間隔 $280 \mathrm{~cm}$ ）を挟んで構えた時, 引き 技の条件では開始線間での身体接触時であった。 4 回の準備試行の後, 本試行を実施した。また, しかけ技と引き技の条件は交互に行った。各条件 の第 1 試行の開始直前に, 防御者（経験年数 16 年）は 1 条件を 1 度だけ約 $1 \mathrm{~s}$ 間呈示して再度構え なおした。その後，被験者は即座に適合する攻撃 をして，防御者は被験者の打撃動作の開始時に， 前呈示した条件で防御した. 1 条件への攻撃の機 会は連続 5 試行に限定し, 1 試行に 1 回のみの攻 撃が許された。また，18条件の呈示の順序は被 験者毎にランダムに決定した（図 $2 \mathrm{~A}$ ).

攻撃の成功の判定は，実験者と防御者が共に成 功と判断したときとした。条件は, 防御者 1 名が
十分な練習を行った上で呈示し，全ての被験者が 同じ条件と手順で実験課題を遂行した。

(3) 分析項目

(1)時間効率

技能確認実験の時間効率を分析した。 全ての試 行を 2 台のビデオカメラ（30fps）で撮影して, 試行の開始（第 1 試行のみ防御者が条件の前呈示 を開始したとき）から打撃動作の開始（打撃動作 のための身体・竹刀の移動）までの時間を測定し た。そして, 各被験者の 18 条件の時間を各試行 数（最高 5 回）で除算して 1 試行の平均時間を計 算し, 各群における各難度の時間効率を算出した。

\section{(2)技能発揮}

技能確認実験における技能発揮の得点を分析し た。各被験者の 18 条件における攻撃の成功を 100 点満点で得点化した。得点は, 全 5 試行の失敗が 最低得点 ( 0 点), 第 1 試行での成功が最高得点 （5.56点）として, 各群における各難度の技能発 揮の得点を算出した.

3）反応選択実験

技能確認実験と同じ実験条件に対する反応選択 の処理効率の熟練差を検討した。

（1）実験条件

実験条件は，技能確認実験と同様であった。

（2）実験手順

実験環境, 試行の開始, 全 18 の条件, 攻撃の 成功の判定基準は技能確認実験と同様であった。 また，実験者は試合のつもりで実験課題に参加す るように被験者に教示した。

技能確認実験との相違点は, 10 回の準備試行, しかけ技と引き技の条件の 1 試行ずつの交互試 行，そして，1つの条件を 5 回連続して呈示する 間に防御者が攻撃する試行をランダムに組み込ん だことであった。この攻撃の試行は, 実験課題に 対戦相手による攻撃可能性の環境干渉を付与する ことになる. 加えて，条件の前呈示がないため, 実戦環境と類似していたといえる。しかし，各条 件において防御者はランダムな攻撃の試行を挟ん で5回連続で同じ条件を呈示する。このような事 象は被験者の熟練水準では希に生じ, 攻撃の成功 のために有効な文脈情報が与えられることになる 
A

技能確認実験

攻撃成功

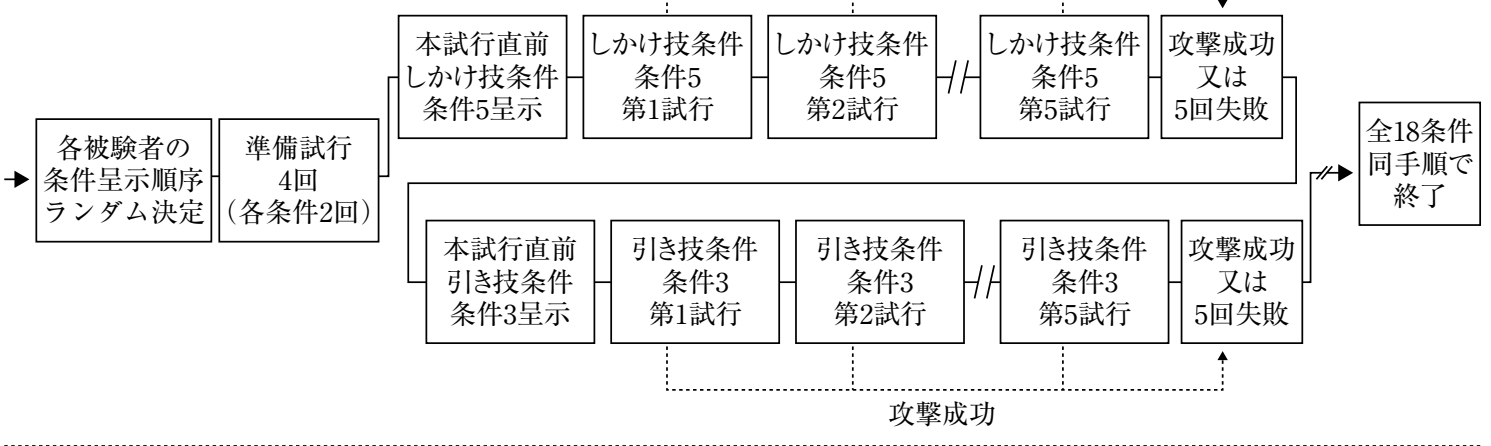

B

反応選択実験

各被験者の

条件呈示順序

ランダム決定 (各条件5回)
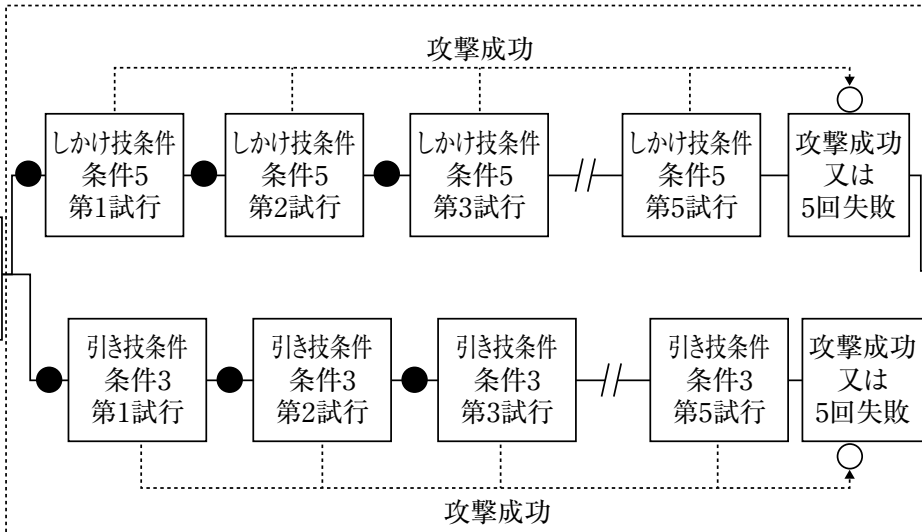

※しかけ技条件から開始し各条件は1試行ずつの交互試行．一方の条件が 先に終了したときは，他方の条件が終了するまで勝負試行（制約なし， 実戦と同様）を継続。：防御者の攻撃試行をランダムに挿入. ○：攻 撃成功直後に思考内容と技知識の活用の有無を報告.

図2 技能確認・反応選択実験における実験手順の例

(図 2B).

防御者は，各試行の直前に，実験者が出す防 御・攻撃の合図を被験者が観察できない位置で確 認した。また，試行中には，条件を呈示（防御） する前に試合と同様に身体の移動などをした。条 件を呈示するにあたって人為的エラーがあったが (全 288 課題中 3 課題), 再実験によって全被験者 が同じ条件と手順で実験課題を遂行した。

(3) 分析項目

(1)思考内容

反応選択の時間と正確性といった処理効率とは 別に，処理様相を具体的に検討するために言語報 告に基づいて思考内容を分析した。

\section{i）処理情報}

被験者は, 反応選択実験において攻撃に成功し た直後, 実験環境に備えられたテープレコーダー に思考内容を記録した（図 $2 \mathrm{~B})$ 。質問は「あなた は打撃前から打撃時にかけて何を考えていました か」であった。実験後, 回答を言語データとして 忠実に文章化した。そして, 先行研究 (French et al., 1996 ; McPherson, 1999, 2000 ; McPherson and Thomas，1989）に準じて量的分 析をするために，評価者 2 名が個別に言語デー夕 を以下の 3 つの概念に分類した（表 1 ）.

(i) 目的概念：目的の情報

（ii）環境概念：目的達成のために動作を適用 する環境の情報 
表 1 言語データの概念分類の例

\begin{tabular}{|c|c|c|}
\hline 処理情報 & $\begin{array}{l}\text { 文脈 } \\
\text { 情報 }\end{array}$ & $\begin{array}{c}\text { 処理 } \\
\text { 段階数 }\end{array}$ \\
\hline $\begin{array}{l}\text { 相手が何度も面を警戒していた } \\
\text { ので（環境；文脈） } \\
\text { 一度面を見せて（動作） } \\
\text { 面を防御したところを（環境） } \\
\text { 胴を打ちました（動作） }\end{array}$ & 有 & 4 \\
\hline $\begin{array}{l}\text { 相手の手元を上げるために（目 } \\
\text { 的） } \\
\text { 竹刀を押さえて（動作） } \\
\text { 相手の手元が上がったところを } \\
\text { (環境) } \\
\text { 小手を打ちました（動作） }\end{array}$ & 無 & 4 \\
\hline $\begin{array}{l}\text { 小手に一度フェイントを入れて } \\
\text { (動作) } \\
\text { 小手を防いだときに（環境） } \\
\text { 回して面を打ちました（動作） }\end{array}$ & 無 & 3 \\
\hline $\begin{array}{l}\text { 相手の手元が浮いたところを } \\
\text { (環境) } \\
\text { 小手を打ちました（動作） }\end{array}$ & 無 & 2 \\
\hline
\end{tabular}

（iii）動作概念：目的達成のために選択された 動作の情報

概念の分類後，1つの言語報告における目的, 環境，動作概念の平均を算出し，各群の平均を計 算した。なお，その他の概念（感情など）も僅か に報告された。

\section{ii）文脈情報}

文脈情報（現在よりも以前の試行の情報）の活 用頻度を，i）処理情報と同様に各群で計数した （表 1）。i）処理情報と, ii）文脈情報における評 価者間の一致率は $92 \%$ あった。，不一致データ は, 評価者間での意見交換に基づいて完全に一致 するように再度分類した。

iii) 処理段階数

1つの言語報告における総概念数の平均を算出 して，各群の平均を計算した（表1）。

(2)知識活用

意図的な知識活用のための処理機能の相違を観 察するために以下の手続きを実施した。

被験者は各条件の低・中難度に対する技知識を 獲得していた。ここでは，その技知識の活用の頻 度を分析した。手続きとして, 知識確認実験で報
告された技知識の動作を 2 台のビデオカメラで撮 影し（30fps）, 被験者毎に映像ファイルとして保 存した。

被験者は, 反応選択実験で攻撃に成功した場合， 思考内容の記録の直後に，攻撃のために技知識を 活用したかどうかを自身の映像ファイルを参照し て報告した（図 $2 \mathrm{~B})$ 。その後, 各群における知識 活用の頻度を算出した。加えて, 知識確認実験で 未報告の技知識を反応選択実験で意図的・創造的 に活用して攻撃に成功したことがあったかどうか を確認した。

なお，被験者に上述のデー夕収集の手順を実験 に参加する前に 20 回以上に渡って経験させ, 実 験事態の新奇性による影響を除去した。

(3)時間効率

技能確認実験と同様に各群における各難度の時 間効率を算出した。

(4)技能発揮

技能確認実験と同様に各群における各難度の技 能発揮の得点を算出した。

(5)実験手順への質問

反応選択実験の終了後, 被験者に 5 回連続した 同じ条件の呈示を認識していたかどうかを確認し た。

\section{3. 分析方法}

反応選択実験における(1)思考内容のi）処理情 報と, iii）処理段階数はMann-WhitneyのU 検定, ii）文脈情報は観測值の直接確率計算を行った。 また，(2)知識活用についても観測值の直接確率計 算を行った。技能確認・反応選択実験の時間効率 （分析項目 (1)(3)）と技能発揮（分析項目 (2)(4)）で は, 3 要因 $(2$ 群 $\times 2$ 実験課題 $\times 3$ 難度 $)$ の分散分 析を行い, 多重比較にはScheffé検定を用いた。 また，全ての分析で有意水準を $5 \%$ とし，有意傾 向の水準を $10 \%$ とした。

\section{III 結 果}

本研究では, 反応選択の熟練差に焦点を当てて いるため, 反応選択実験の分析項目に準えて結果 
表 2 反応選択実験における各群の思考内容と技知識の活用頻度

\begin{tabular}{|c|c|c|c|c|}
\hline & & & 準熟練群 & 熟練群 \\
\hline \multirow{7}{*}{ 思考内容 } & \multirow{4}{*}{ 処理情報 } & 目的 & $0.5 \quad(0.4)$ & $0.5(0.4)$ \\
\hline & & 環境 & $1.1 \quad(0.4)$ & $1.0(0.2)$ \\
\hline & & 動作 & $2.1(1.0)$ & $2.2(0.4)$ \\
\hline & & その他 & $0.2 \quad(0.2)$ & $0.2 \quad(0.2)$ \\
\hline & \multirow{2}{*}{ 文脈情報 } & 活用 & 6 & 13 \\
\hline & & 非活用 & 38 & 58 \\
\hline & \multicolumn{2}{|c|}{ 処理段階数 } & $4.0(0.8)$ & $3.9(1.3)$ \\
\hline \multirow{2}{*}{ 技知識 } & \multirow{2}{*}{\multicolumn{2}{|c|}{$\begin{array}{c}\text { 活用 } \\
\text { 非活用 }\end{array}$}} & 22 & 54 \\
\hline & & & 22 & 17 \\
\hline
\end{tabular}

処理情報 - 処理段階数: M $(S D)$, 文脈情報 - 技知識数 $: n$
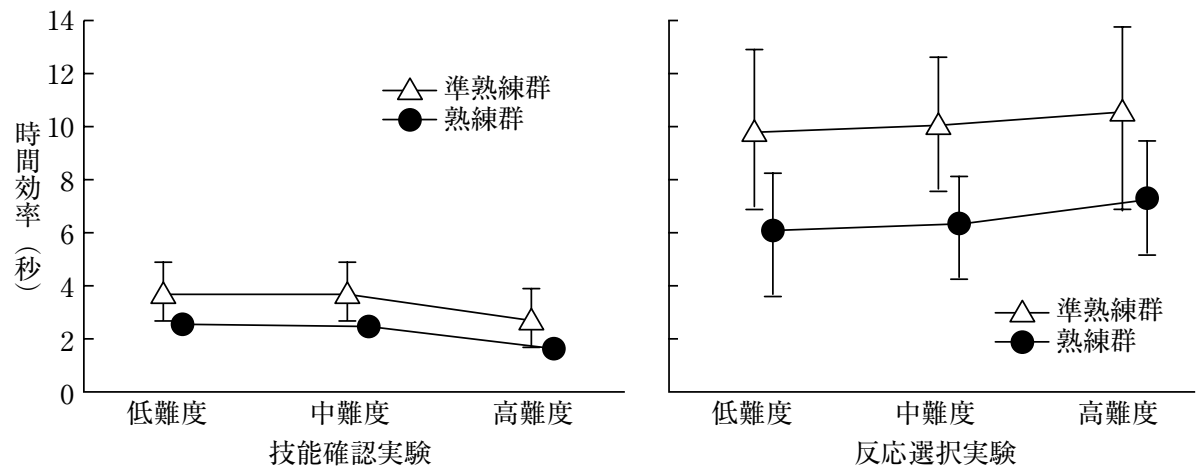

図3 技能確認 - 反応選択実験における各群の時間効率

および考察を記述する。

\section{1. 思考内容}

1）処理情報

各群における目的，環境，動作概念の頻度の平 均に有意差は認められなかった（表 2$)$.

2）文脈情報

各群における文脈情報の活用頻度の偏りに有意 差は認められなかった（表2).

3) 処理段階数

各群における処理段階数の平均に有意差は認め られなかった（表2）。

\section{2. 知識活用}

熟練群は準熟練群と比べて知識活用の頻度が高 く, 各群における知識活用の頻度の偏りは有意で
あった（両側検定： p <.01：表 2)。また，知識 確認実験において未報告の技知識を反応選択実験 で意図的・創造的に活用して攻撃に成功したと回 答した被験者はいなかった。

\section{3. 時間効率}

各群における時間効率では（図 3), 実験課題 と難度の 1 次の交互作用に有意差が認められ（F $(2,28)=16.25, \mathrm{p}<.01)$, 実験課題と群の 1 次の 交互作用に有意傾向が認められた $(\mathrm{F}(1,14)=$ $3.71, \mathrm{p}<.10)$.

実験課題と難度では，全ての難度で技能確認実 験の方が短時間で試行していた。また，技能確認 実験は高難度が低・中難度より短時間で試行して おり，反応選択実験は相違がなかった。つまり， 技能確認実験における高難度の時間が短いために 

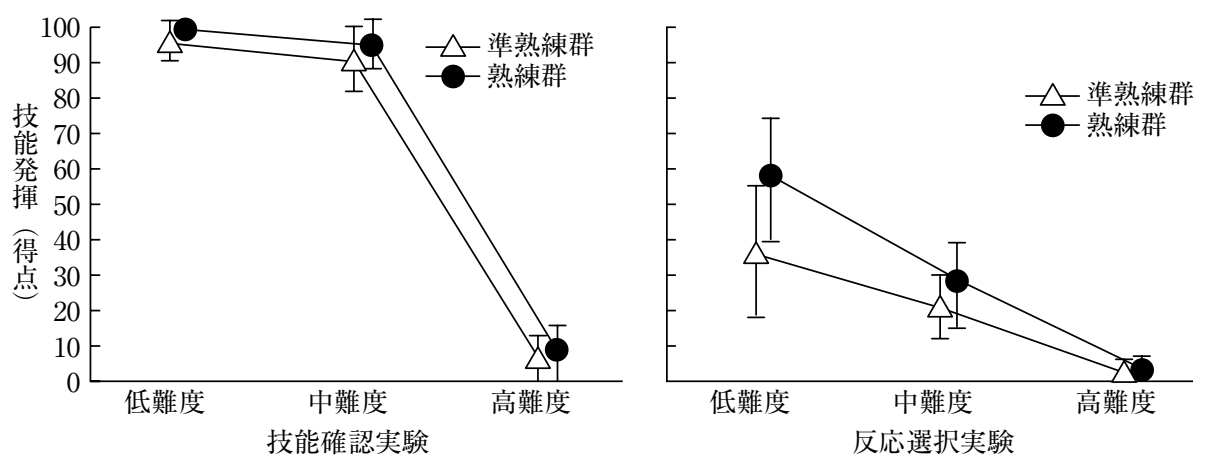

図4 技能確認 . 反応選択実験における各群の技能発揮得点

交互作用がみられた。

実験課題と群では，両群で技能確認実験の方が 短時間で試行していた。また，両実験課題におい て熟練群の方が短時間で試行していた。つまり， 実験課題における各群の相違の傾向は同じであ り，交互作用は確認されなかった。

\section{4. 技能発揮}

各群における技能発揮の得点では（図 4), 実 験課題と難度の 1 次の交互作用に有意差が認めら れ $(\mathrm{F}(2,28)=69.54, \mathrm{p}<.01)$, 実験課題と群 の 1 次の交互作用に有意傾向が認められた（F $(1,14)=3.14, \mathrm{p}<.10)$.

実験課題と難度では, 全ての難度で技能確認実 験の方が高得点であった。技能確認実験は低・中 難度が高難度より高得点であり, 反応選択実験は 低難度が中・高難度よりも，また中難度が高難度 よりも高得点であった。つまり，技能確認実験の 中難度が高得点であったので交互作用がみられ た。

実験課題と群では，両群で技能確認実験の方が 高得点であった。また，技能確認実験では群間の 差異がなく, 反応選択実験は熟練群の方が高得点 であった。つまり, 反応選択実験で熟練群が高得 点であったので交互作用がみられた。

\section{5. 実験手順への質問}

全ての被験者は，反応選択実験において同じ条 件が 5 回連続して呈示されたことを認識していな
かった。

\section{IV 考察}

\section{1. 思考内容}

1）処理情報

処理情報において群間の相違はなかった。つま り，簡潔で抽象的な質問によって思考内容を抽出 した場合，意識レベルの言語報告で再生が可能な 処理情報に相違はなかったのである。大学生の熟 練選手と初心者を比較した先行研究 (McPherson，1999，2000）では熟練差があったが，本研 究では群間の熟練水準が近接していたために差異 が観察されなかったと考えられる。

2）文脈情報

文脈情報の活用の頻度に群間の相違はなく，ま た 5 回連続の同じ条件の呈示にもかかわらず低い 頻度であった。だが，卓球の世界トップレベルの 熟練選手は，試合の前半で対戦相手の反応などの 情報を収集して，後半でその情報を多用すること が示されている（Sève et al., 2002 ; Sève et al., 2003)。被験者の熟練水準の相違によるものとも 考えられるが，これは卓球と剣道の競技特性から 説明が可能である。卓球は，数 10 分の試合時間 の中で得失点が頻繁に生じるため, 意図的に失点 することはなくとも，対戦相手の情報収集のため に時間と得点を配分する機会を設けることができ る。一方, 剣道は, 相対的に試合時間が短く中断 が少ないために熟考する時間がない上に，攻撃の 
成功の頻度が少ないことから得点の争奪の利得と 損失が大きい。そのため，時間や得点を配分して 情報収集をすることが難しい。つまり，剣道の競 技特性上の制約が，文脈情報の活用を抑制したと 考えられる。

\section{3) 処理段階数}

処理段階数において群間の相違はなく，4段階 程度であった。また，処理情報の結果を参照する と,「自己の準備動作-相手の反応-自己の打撃動 作」の簡潔な思考内容が多かったといえる．先行 研究の説明（たとえば，McPherson，1999, 2000）に準えると，「if［反応］- then［動作］」 の「if」の前に能動的な準備動作が入る「if [準 備動作］ - then [if［反応］- then [打撃動作］」 の思考となる。この簡潔な思考内容には，時間制 約や，生起する事象の系列予測の困難さなどの競 技特性が影響していると考えられる。

\section{2. 知識活用}

熟練群は知識活用の頻度が高く，技知識を意図 的に検索し活用する処理機能に熟練差が認められ た。思考内容の結果を踏まえて考えると, 熟練群 は「準備動作一反応-打撃動作」の情報を分節化し て処理するのではなく，それらの情報を結合した 技知識を獲得した上で積極的に多用することを示 している，ただし，この処理では，その知識活用 が可能な環境であることを準備動作の遂行前に認 識する必要がある。一方，準熟練群は，そのよう な処理が半数であった。この知識活用の熟練差に よる処理様相の相違については総合考察で具体的 に述べる。

また, 先行研究 (Ericsson and Kintsch, 1995 ；McPherson and Kernodle，2003）の説明 から考察すると, 熟練群のように知識を繁用する ことは, 修正点の発見を促して知識を洗練するこ とを可能にすると想定される，加えて，対戦相手 の攻撃のような環境干渉への耐性をもたらし，知 識活用のための処理機能を頑健にすると考えられ る.すなわち, その反応選択は, 知識と処理機能 のための認知的学習をもたらすと推測される。一 方，準熟練群は，認知的学習の側面から見ると改
善の余地があり，干渉のある環境において検索と 活用が困難な知識と処理機能を持つことを意味し ている。

\section{3. 時間効率}

両群は技能確認実験における試行の時間が短 く，両実験課題において熟練群は短時間で試行し た.また，反応選択実験における各群の時間増加 の差異は注目に值する。

技能確認実験の結果は，環境情報を符号化する 能力の影響が考えられるが (Mori et al., 2002 ; Williams and Elliott, 1999), 事前に条件の呈示 （約 1s）があり，条件を同定する時間は充分にあ った。つまり，反応選択のための最低限の時間効 率を示しており，熟練群の効率の良さは反応選択 の迅速化や修正を可能にすると考えられる。

そして，剣道では速度よりも正確な反応選択が 要求されるにもかかわらず, 反応選択実験におい て熟練差が顕著になる。これは，知識活用におい て考察したような干渉耐性の差異を示しており， 熟練群の処理機能の頑健性が迅速な反応選択をも たらしたと考えられる。一方で，準熟練群は，処 理機能の干渉への脆弱性が影響して遅延が生じた と想定される.

また，技能確認実験における高難度の条件が最 も短時間で試行されたために交互作用がみられ た。実験課題の観察では, 被験者は試行の開始直 後に攻撃することが多かった。つまり，条件の前 呈示によって攻撃の困難さを認識し, 開始直後に 攻撃する方法を頻繁に採択した結果が影響したの である。

\section{4. 技能発揮}

技能確認実験の結果から，低・中難度に対する 被験者の運動技能の獲得が概ね確認された。つま り, 反応選択実験における低・中難度の結果に技 知識や運動技能のような情報資源の相違が大きく 影響するものではない。しかし，反応選択実験の 干渉がある環境において, 熟練群が適切な反応選 択と運動技能を発揮する優れた能力があることが 示された. 
この結果は，知識活用の熟練差が少なからず影 響しているとみなせる。技知識は動作や処理の反 復活用によって獲得される。 また，技知識を活用 するときには，動作を事前に決定して，遂行前に 動作を微調整する時間を設けることが可能になる と考えられる.すなわち, 熟練群は正確な動作遂 行をした可能性が高い。一方で，準熟練群は，知 識活用の頻度が少ないことから，環境に瞬間的に 対応する反応選択が多くなり，結果的に正確性を 欠く動作遂行をする傾向にあったと考えられる。

なお，両実験課題における高難度の得点の低下 は，難度の高さと技知識の欠如の両方が影響した と想定される。

\section{5. 総合考察}

結果をまとめ, 処理様相と処理機能から反応選 択の処理効率の熟練差について具体的に考察す る.

反応選択実験において防御者は，被験者の打撃 動作の開始時に条件を呈示 (防御) したことから， 被験者は防御動作を観察した後に受動的で瞬間的 に対応する反応選択をしたのではない。また，文 脈情報の活用の頻度は低く, 過去に生起した事象 に基づき予測して反応選択をすることは少ない。 そして，思考内容は「if［準備動作］- then［if [反応］- then [打撃動作]]」であった. 熟練差 は, 反応選択実験における技知識の活用の頻度に あった。この技知識の活用による反応選択の処理 様相と，それをもたらす処理機能の相違が，時間 効率と技能発揮の熟練差を生み出したと考えられ る.

まず，処理様相の相違については，実戦場面の 観察においてフェイント動作などを遂行して攻撃 をするときに対戦相手の反応を確認するための動 作の停滞がほとんど見られないこと，そして，被 験者が知識確認実験において未報告の技知識を反 応選択実験で意図的・創造的に活用して攻撃に成 功していない事実から次のように考えられる。技 知識を活用する場合，遂行する動作を事前に決定 しているため, 攻撃者は準備動作の後（if［準備 動作），防御者の反応の有無にかかわらず (then [if [反応]），反応を予測して能動的に打 撃動作をする（then［打撃動作］：熟練群の約 $75 \%$ : 表2)。一方，技知識を活用しない場合は， 準備動作の後（if［準備動作］），防御者を観察し て「打てるかもしれない」という情報（防御動作 ではない）が呈示されるまで（then [if [反応]］） 攻撃を待機して受動的に瞬間的に対応して打撃動 作をする（then［打撃動作］：準熟練群の $50 \%$ ：表 2)。前者は反応の予測によって準備動 作から打撃動作までの処理が一連となっている. 一方, 後者は準備動作と以後の処理が分節化され, 反応を観察した後に打撃動作に移行することにな る。

時間効率の相違については，まず，反応選択の ための処理機能の干渉耐性の頑健性と脆弱性の熟 練差が大きく影響したと考えられる，さらに，技 知識を活用しない場合, 攻撃の機会を待機するた め反応選択の時間が長くなる傾向にあると考えら れる。 その傾向は，反応選択実験の時間効率にお ける知識の活用と非活用場面における各群の時間 効率にも僅かに表れている（群の場面平均（標準 偏差）は，準熟練群：活用 $11.0 （ 6.7 ） \mathrm{~s}$ ，非活用 13.4（6.5） s，熟練群：活用 6.1（2.2） s, 非活用 6.8 (4.1) s).

ここで, 環境の干渉と攻防の数 $100 \mathrm{~ms}$ の展開 を踏まえると，一般的には技知識を活用すること が困難になると想定される。そこでも，熟練群の 処理機能の頑健性は，干涉への耐性を発揮して知 識活用を可能にする。一方, 準熟練群は, 処理機 能が干渉に対して脆弱であるために知識を活用す ることができなくなる。

最終的に，この技知識を活用した予測による能 動的な反応選択は，技能発揮の考察で述べたよう に正確な動作遂行をもたらす。一方, 環境へ受動 的かつ瞬間的に対応する反応選択は, 正確性を欠 く動作遂行を導くと考えられる.

上述したことから, 反応選択における処理様相 の能動性・受動性の相違と, 処理機能の干渉耐性 の頑健性・脆弱性の差異が, 時間効率と技能発揮 の処理効率の熟練差を生み出したと考えられる.

剣道において予測による能動的な反応選択の重 
要性が示されたが，これは，ベースボール (French et al., 1996 ; Nevett and French, 1997), 卓球 (Sève et al., 2002 ; Sève et al., 2003), テ ニス（McPherson，1999，2000）における熟練 選手の環境情報に基づく受動的な反応選択とは異 なる，この相違は, 環境情報（たとえば，ボール） に対応する必要がある競技と, 動作によって対戦 相手を直接動かして反応を予測することが可能な 競技の特性上の相違が影響したと考えられる。つ まり, 反応選択のために有効な処理様相が競技特 性によって異なることが明確となった。

競技実践者や指導者への提言は，競技特性を踏 まえた上で，獲得した知識を活用した予測的・能 動的な反応選択を 1 つの学習指標として位置づけ ることである，具体的には，まず，競技に有効な 知識を獲得するために, 構成要素となる下位の知 識や運動技能を獲得する必要がある(奥村・吉田, 2002). そして, 反応選択において獲得した知識 を活用する処理を習慣化する中で, 知識の内容を 改善すると同時に, 処理機能の干渉耐性を頑健に することが重要になる，ただし，注意すべきは， 剣道のような特性を持つ競技であっても, 環境次 第で文脈情報の活用や, 環境への瞬間的対応など の受動的な反応選択が重要になる点である.さら に，動作遂行中にも環境情報に合わせながら動作 を調整する知覚-動作結合による連続制御（たと えば, Bootsma et al., 1991 ; Matsuo and Kasai, 1994）も重要となる.しかし，このような処理や 動作遂行の効率や熟練差は, 分析機器の限界と研 究の観点の相違のために明確ではない.これらは, 試合などの実環境における分析を含め今後の検討 課題である.

\section{$V$ 要 約}

本研究では, 熟練・準熟練群の大学生の剣道選 手における反応選択の処理効率の熟練差を検討し た。ここでは, 被験者の技知識を確認して実験条 件を設定した，そして，その条件に対する運動技 能の獲得度合と, 反応選択の処理効率を検討する 2 実験課題を実施した。まず，技能確認実験では
熟練差はなく, 条件の低・中難度に対する両群の 運動技能の獲得が概ね確認された。反応選択実験 では, 技知識の活用頻度, 時間効率, 技能発揮に おいて熟練差が認められた. 熟練群の思考内容と 技知識の繁用は, 予測による能動的な反応選択を 多用することを示していた。また，その知識の繁 用は, 環境に存在する干渉への耐性を頑健にする ように処理機能を向上させる.一方, 準熟練群は, 処理機能が干渉に対して脆弱であるために技知識 を活用することができず，受動的な反応選択を強 いられると考えられた。この採用する処理様相の 能動性 - 受動性と処理機能の頑健性 - 脆弱性の相 違が, 反応選択における時間効率と技能発揮の処 理効率の熟練差をもたらしていた.すなわち, 剣 道では，技知識を活用した予測による能動的な反 応選択が重要であることが示された。競技実践者 は, 有効な技知識を獲得し, 反応選択でこれを多 用する中で, 知識の洗練と処理機能の強化を図る ベきである.

\section{文献}

Anderson, J.R. (1987) Skill acquisition: compilation of weak-method problem solutions. Psychological Review, 94: 192-210.

Bootsma, R.J., Houbiers, M.H.J., Whiting, H.T.A., and van Wieringen, P.C.W. (1991) Acquiring an attacking forehand drive: the effects of static and dynamic environmental condition. Research Quarterly for Exercise and Sport, 62: 276-284.

Ericsson, K.A. and Kintsch, W. (1995) Long-term working memory. Psychological Review, 102: 211245.

French, K.E., Nevett, M.E., Spurgeon, J.H., Graham, K.C., Rink, J.E., and McPherson, S.L. (1996) Knowledge representation and problem solution in expert and novice youth baseball players. Research Quarterly for Exercise and Sport, 67: 386-395.

French, K.E. and Thomas, J.R. (1987) The relation of knowledge development to children's basketball performance. Journal of Sport Psychology, 9: 1532.

Masson, M.E.J. (1990) Cognitive theories of skill ac- 
quisition. Human Movement Science, 9: 221-239.

Matsuo, T. and Kasai, T. (1994) Timing strategy of baseball-batting. Journal of Human Movement Studies, 27: 253-269.

McPherson, S.L. (1999) Tactical differences in problem representations and solutions in collegiate varsity and beginner female tennis players. Research Quarterly for Exercise and Sport, 70: 369-384.

McPherson, S.L. (2000) Expert-novice differences in planning strategies during collegiate singles tennis competition. Journal of Sport and Exercise Psychology, 22: 39-62.

McPherson, S.L. and Kernodle, M.W. (2003) Tactics, the neglected attribute of expertise: problem representations and performance skills in tennis. In: Starkes, J.L. and Ericsson, K.A. (Eds.) Expert performance in sport: advances in research on sport expertise. Human Kinetics: Champaign, pp. 137168.

McPherson, S.L. and Thomas, J.R. (1989) Relation of knowledge and performance in boys' tennis: age and expertise. Journal of Experimental Child Psychology, 48: 190-211.

Mori, S., Ohtani, Y., and Imanaka, K. (2002) Reaction times and anticipatory skills of karate athletes. Human Movement Science, 21: 213-230.

Nevett, M.E. and French, K.E. (1997) The development of sport-specific planning, rehearsal, and updating of plans during defensive youth baseball game performance. Research Quarterly for Exercise and Sport, 68: 203-214.

奥村基生・吉田 茂（2002）大学剣道選手における 攻撃動作パターンの知識構造. スポーツ心理学研 究, $29: 30-40$.

Sève, C., Saury, J., Ria, L., and Durand, M. (2003) Structure of expert players' activity during competitive interaction in table tennis. Research Quarterly for Exercise and Sport, 74: 71-83.

Sève, C., Saury, J., Theureau, J., and Durand, M. (2002) Activity organization and knowledge construction during competitive interaction in table tennis. Cognitive Systems Research, 3: 501-522.

Starkes, J.L. and Ericsson, K.A. (2003) Expert performance in sports: advances in research on sport expertise. Human Kinetics: Champaign.

Tenenbaum, G. (2003) Expert athletes: An integrated approach. In: Starkes, J.L. and Ericsson, K.A. (Eds.) Expert performance in sport: advances in research on sport expertise. Human Kinetics: Champaign, pp. 191-218.

Williams, A.M., Davids, K., and Williams, J.G. (1999) Visual perception and action in sport. E and FN Spon: London.

Williams, A.M. and Elliott, D. (1999) Anxiety, expertise, and visual search strategy in karate. Journal of Sport and Exercise Psychology, 21: 362-375.

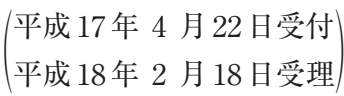

